\title{
Correction: Epalrestat, an Aldose Reductase Inhibitor, Restores Erectile Function in Streptozocin-induced Diabetic Rats
}

\author{
Bai-Bing Yang ${ }^{1} \cdot$ Zhi-Wei Hong $^{2} \cdot$ Zheng Zhang $^{1} \cdot$ Wen $\mathrm{Yu}^{1} \cdot$ Tao Song $^{1} \cdot$ Lei-Lei Zhu ${ }^{1} \cdot$ He-Song Jiang ${ }^{1}$. \\ Guo-Tao Chen ${ }^{1} \cdot$ Yun Chen ${ }^{3} \cdot$ Yu-Tian Dai ${ }^{1}$
}

Published online: 4 February 2019

(c) The Author(s) 2019. This article is published with open access

\section{Correction to: International Journal of Impotence Research; https://doi.org/10.1038/s41443-018-0075-x; published online 13 September 2018}

This Article was originally published under Nature Research's License to Publish, but has now been made available under a CC BY 4.0 license. The PDF and HTML versions of the Article have been modified accordingly.
Open Access This article is licensed under a Creative Commons Attribution 4.0 International License, which permits use, sharing, adaptation, distribution and reproduction in any medium or format, as long as you give appropriate credit to the original author(s) and the source, provide a link to the Creative Commons license, and indicate if changes were made. The images or other third party material in this article are included in the article's Creative Commons license, unless indicated otherwise in a credit line to the material. If material is not included in the article's Creative Commons license and your intended use is not permitted by statutory regulation or exceeds the permitted use, you will need to obtain permission directly from the copyright holder. To view a copy of this license, visit http://creativecommons. org/licenses/by/4.0/.

These authors contributed equally: Bai-Bing Yang, Zhi-Wei Hong.

The original article can be found online at https://doi.org/10.1038/ s41443-018-0075-x.

\footnotetext{
Yun Chen

chenyunnju@163.com

$\triangle$ Yu-Tian Dai

13913957628@163.com

1 Department of Andrology, Drum Tower Hospital, Medical School of Nanjing University, Nanjing 210000, China

2 Department of Urology, Fujian Provincial Hospital, Fuzhou 350000, China

3 Department of Andrology, Jiangsu Provincial Hospital of Traditional Chinese Medicine, Nanjing 210000, China
} 